\section{ECONOMICS}

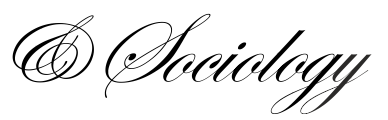

\title{
THE EFFECTS OF ETHICAL ORIENTATION, INDIVIDUAL CULTURE AND ETHICAL CLIMATE ON ETHICAL JUDGEMENT OF PUBLIC SECTOR EMPLOYEES IN MALAYSIA
}

\author{
Razana Juhaida Johari \\ Faculty of Accountancy, \\ UiTM Shah Alam, 40000 Shab \\ Alam, Selangor, Malaysia \\ E-mail:razana@uitm.edu.my
}

\section{Ida Rosnidah}

Faculty of Economics,

Universitas Swadaya Gunung Jati,

Cirebon, Indonesia

E-mail:idarosnidab@gmail.com

Siti Syazana Ahmad Nasfy

Faculty of Accountancy,

UiTM Shah Alam, 40000 Shah

Alam, Selangor, Malaysia

E-mail:shazanasfy@gmail.com

\section{Sayed Alwee Hussnie Sayed Hussin \\ Jabatan Audit Negara, \\ Pusat Pentadbiran Kerajaan \\ Persekutuan, 62518 Putrajaya, \\ Malaysia \\ E-mail: \\ zuraidahms@salam.uitm.edu.my}

Received: July, 2019

1st Revision: December, 2020

Accepted: February, 2020

DOI: $10.14254 / 2071-$

789X.2020/13-1/9

JEL Classification: M41
ABSTRACT. Recently, many unethical practices among public sector officer in Malaysia have been exposed. Issues related to unethical judgement of public sector officers such as corruption, misappropriation of assets, abuse of power, and misconduct of duties have been widely reported. As such, citizens are generally sceptical of public sector officers and hold them accountable for their failure in making ethical judgements. Specifically, this study is conducted with the aim to analyse the influence of ethical orientation, individual culture and ethical climate on the ethical judgement of public sector officers in the selected Malaysia public sectors. The data is analysed based on 176 responses of a questionnaire survey. The findings of the study show that the idealistic ethical orientation and individual culture significantly influence the ethical judgement of public sector officers. However, relative ethical orientation and ethical climate show no relationship on the public sector officers' ethical judgement. This study contributes to literature through better understanding of the influence of the three independent variables (ethical orientation, individual culture and ethical climate) on the ethical judgement among public sector officers in Malaysia. Hence, this study will be useful to the public sector agencies in their effort to improve the ethical conduct of their officers in making judgement for the benefit of the citizens and the nation. The study also provides recommendations on how to improve the credibility and viability of public sector delivery systems towards fulfilling the needs of the public at large.

Keywords: Public sector officers, ethical judgement, ethical orientation, individual culture, Malaysia 


\section{Introduction}

A public sector administrator is an agent who links the government with the citizens. In other words, it transmits information and resources from the state to the citizens. To serve these tasks, it is very important to ensure that public sector administration is efficient, transparent and ethical. Hence, public sector administrations have been constantly reformed from time to time to deliver the best service to the citizens. Consequently, administrative reforms are undertaken in the public sector in order to ensure that public sector officers perform their duties ethically and in a transparent manner without involving any personal interest that could affect public sector administration as well as the development of the country. In the meantime, public sector officers are those who are appointed by the government to assist in meeting the needs of the citizens (Johari, Alam \& Said, 2018). Hence, it is very important to ensure that public sector officers are able to perform their duties ethically and responsibly.

Recently, there have been many issues concerning unethical judgement of public sector officers among which are corruption, misappropriation of assets, abuse of power, and misconduct of duties. These scenarios have raised many questions on the ethicality of the public sector officers, particularly on their ethical judgement of those issues. The occurrences of scandals, such as the Port Klang Free Zone (PKFZ) scandal, have tarred the reputation of the public sector officers as well as that of the government overall. Such scandals indicated that the public sector officers failed to perform their duties ethically and uphold the public trust (Alam, Johari \& Said, 2018). According to the Transparency International Corruption Perception Index, in 2013 Malaysia was ranked 53rd among 177 (from the least corrupt to the most corrupt) and in 2014 Malaysia was ranked 50th among 1-175. Even though the rank reduced in 2014, internal corruption cases continued to be reported and due to this Malaysia has become the target of on-going criticism for reportedly high levels of unethical conduct in government agencies, including corruption. The continuity of unethical conduct and the current index of Transparency International Corruption Perception clearly justify the need to immediately address the ethical judgement of public sector officers in order to prevent the occurrences of unethical conduct from becoming more acute and thus adversely affecting the economy and national development.

In the meantime, public sector officers are facing a variety of situations that undermine their credibility in making ethical judgements while performing their duties. From the previous studies it is evident that the way an individual makes decisions when facing ethical dilemmas would be affected by this individual's ethical orientation (Forsyth, 1980; Barnett, Bass \& Brown, 1994). Hence, differences that exist in one's ethical orientation can result in disagreements about what is ethical and how an individual should be sensitive in making their ethical judgements. This strongly suggests that ethical orientation can influence ethical judgements depending on the severity of the ethical dilemma. Therefore, this study aims to investigate whether ethical orientations have a significant influence on the public sector officers' ethical judgement.

Apart from the individual ethical dilemmas faced by public sectors officers, individual culture has also been one of the factors that influence individuals in making ethical judgements. According to Burton (2017) and Axinn, Blair and Thach (2004), culture significantly influences individual's beliefs about what is appropriate and inappropriate in terms of ethical behaviour which will consequently influence an individual in making ethical or unethical judgements. Previously, many researchers had investigated the influence of culture towards ethical decisionmaking process (Arnold, Bernadia, Neidermeyer \& Schmee, 2007; Axinn et al., 2004). It was found that individual culture had significant influence towards ethical judgement made by an individual while performing his or her tasks. Therefore, the relationship between individual 
culture and ethical judgement and its effects on one's judgement while performing duties will be examined.

Besides the individual factors, environmental factors can also influence an individual in making ethical judgements. Therefore, the last factor that will be examined here below is the influence of ethical climate on the public sector officers' ethical judgement. According to (Victor \& Cullen, 1987, 1988), ethical climate refers to stable, psychologically meaningful perceptions the members of organizations hold concerning ethical procedures and policies existing in their organizations and organizational subunits.

Previous studies also proved that organizational work climates could be a significant factor in shaping the behaviours of officers (Dieterly \& Schneider, 1974; McKee, 1988). In other words, ethical climate of an organization can influence an individual in performing their duties, especially in making ethical decision-making. Furthermore, Martin and Cullen (2006) found that ethical climate was a critical factor influencing the officers' perception of how their organization emphasized the ethical aspects of business and encouraged officers' ethical work behaviours. Therefore, it can be concluded that ethical climate will influence an individual's work environment to determine whether will they work in an ethical or unethical environment which consequently may influence them in making ethical or unethical decisions.

\section{Literature review and hypothesis development}

This section discusses relevant past studies that help form hypotheses. Specifically, there are four hypotheses to be tested in this study.

\subsection{Ethical orientation}

According to Sullivan (2007), ethical orientation is defined as an individual's internal tendency towards one perspective either teleology or deontology. The differences in ethical orientation can result in disagreements about what is ethical, and the situation in which a person should be sensitive and about the ethical judgements made by an individual. Barnett et al. (1994) and Forsyth (2008) mentioned that ethical orientation is a major factor that explains the differences in the ethical judgement of individuals. Barnett et al. (1994) also mentioned that ethical orientation as a strong influential factor in explaining the ethical judgement of individuals in unethical dilemmas. This was supported by previous studies such as Abou Hashish and Ali Awad (2017); Bass, Barnett, and Brown (1998) who found that the significant differences in ethical judgements were due to ethical orientation in scenarios judged as most unethical.

On the other hand, Johari, Mohd. Sanusi and Vincent (2017); Jones (1991); Douglas et al. (2001) evaluated the effects of ethical orientation on ethical judgement among accountants and found that ethical orientation is related to ethical judgement in high-moral intensity situations. Therefore, they concluded that ethical orientation could influence ethical decisions or ethical judgements made by individuals depending on the severity of the ethical dilemma.

Therefore, based on the previous findings of the relevant literatures, the hypotheses below are formulated:

H1 (a): There is a significant relationship between idealism and ethical judgement.

H1 (b): There is a significant relationship between relativism and ethical judgement. 


\subsection{Individual culture}

According to Hofstede (1980), culture is a set of norms, values and beliefs of a particular group of community which are shared by its members. Therefore, culture is a mental programming that people share with other members of their nation, region, or group but not with others from different nations, regions, or groups (Hofstede, 1983). Hofstede (1980) also mentioned that culture can be examined at universal, collective, and individual levels. A study by GLOBE defined culture as the shared motives, beliefs, identities and interpretations of significant events that result from common experiences among members of a collective group and are transmitted across generations (House, Hanges, Javidan, Dorfman \& Gupta, 2004).

Previous research found that culture influenced an individual's moral awareness and moral judgement during the ethical decision making process (Burton, 2017; Arnold et al., 2007; Axinn et al., 2004; Singhapakdi et al., 1999). Barnett et al. (1994), in their study found that there were strong links between the individual's intentions as the outcomes of his moral judgement. Wang, Lu \& Liu (2017) and Colby and Kohlberg (1987) found that an individual culture evaluated morality in terms of concepts of right and fairness based on the judgement and equality. Hence, individual cultures encouraged individuals to behave in accordance to rules and regulations and perform ethical judgement.

Therefore, based on the above arguments, the following hypotheses are formulated.

$\mathrm{H} 2$ : There is a significant relationship between individual culture and ethical judgement.

\subsection{Ethical climate}

Victor and Cullen (1987) suggested that the ethical climate in organizations influenced the moral conduct of their membership especially that of their boards of directors. In addition, ethical climate or ethical culture of an organization refers to the shared understanding about what is correct behaviour (Victor \& Cullen, 1987). Meanwhile, Hunt, Wood, and Chonko (1989) in their study rephrased ethical climate as the corporate ethical values where it was defined as "a composite of the individual ethical values of managers and both the formal and informal policies on ethics of the organization", while Martin and Cullen (2006) defined ethical climate as the officers' perception of what constituted ethically right or wrong behaviour, thus, ethical climate became a psychological mechanism through which ethical issues were managed in an organization.

Abou Hashish (2017) and Gonzalez-Padron, Hult, and Calantone (2008) noted that organizational climate that emphasized on ethics would increase the trust and commitment within the organization. For example, Berrone et al. (2007) in his study mentioned that organizations which were perceived to have a high level of corporate ethics had a better performance seen through the satisfaction level of the various stakeholders. A previous study done by Shafer (2008) found that there was significant relationship between ethical climate and ethical judgement. Shafer and Wang (2011) also found a significant influence between ethical climate and ethical judgement. As a conclusion, the ethical climate of an organization can improve an organization's performance and encourage the officers to make ethical judgement.

Therefore, by adapting the link between ethical climate and ethical judgement of public sector officers, the following hypothesis is proposed:

H3: There is a significant relationship between ethical climate and ethical judgement. 


\section{Methodological approach}

\subsection{Sample selection}

The focus of this study is public sector officers' ethical judgement. Therefore, the respondents selected for this study were public sector officers from Malaysian government departments located in Putrajaya and Selangor who managed the government treasury. Four government departments involved in this study were the Accountant General's Department of Malaysia (Jabatan Akauntan Negara), National Audit Department (Jabatan Audit Negara), Royal Malaysian Customs Department - GST Department (Jabatan Kastam Malaysia- Jabatan GST) and Inland Revenue Board of Malaysia (Lembaga Hasil Dalam Negeri). These government departments were chosen because they manage the Malaysian government treasury, collect taxes on behalf of the government and audit the government account.

The convenience sampling method was used whereby the respondents were selected based on their service grade from government departments that dealt with national wealth. This group of respondents was identified as the Management and Professional group (Kumpulan Pengurusan dan Professional) with a service grade of 41 and above. From the four selected government departments, around 40 to 50 officers were identified to be in grade 41 and above. Hence, only 200 questionnaires were distributed to the officers from the four selected government departments.

\subsection{Measurement of variables}

Variables of this study are the assessment of ethical judgement, ethical oriemtation, individual culture and ethical climate. Below are the measurements used for each variables under study.

(i) Ethical Judgement - the questionnaire for ethical judgement is a replication of a study carried out by Stanga and Turpen (1991) and the questionnaire was modified by Amalina et al. (2014). It was modified based on the scenario case question to indicate the likelihood that the respondents would engage in the activity described. It used five ordinal scales which ranged from $1=$ No, I definitely would not, 2 = I probably would not, 3 = I do not know what I would do, 4 = I probably would and $5=$ Yes, I definitely would.

(ii) Ethical Orientation - the measurement of ethical orientations such as Ethics Position Questionnaire (EPQ) was developed by Forsyth in 1980. Originally, Forsyth designed twenty (20) questions that consisted of 10 items each for idealism and relativism. However, this study used the adopted version of EPQ, which consisted of fourteen (14) items by which there were seven (7) questions for idealism and relativism respectively. The scale was verified in Johari, Mohd. Sanusi \& Ismail (2012) and Ismail (2014) in their studies on the Malaysian respondents. This questionnaire used a seven-point Likert scale which ranged from $1=$ strongly disagree to $7=$ strongly agree. The higher scores indicate higher degrees of idealism and relativism.

(iii) Individual Culture - the questionnaire for individualism-collectivism dimension was adapted from Jung (2002) and Maheran (2010). The questionnaire was based on ten (10) items that measured the individualismcollectivism values. It used seven-item Likert scales which ranged from $1=$ strongly disagree to $7=$ strongly agree. The higher score indicated that the 
person was having a dimension of collectivism culture in which they believed on cooperation, helpfulness and consideration of the group's goals. On the other hand, the lower score indicated that a person is more immersed in individualism culture that tended to make decision on his or her own opinion without asking for others'.

(iv) Ethical Climate - this study aims to examine the extent to which the ethical climate influences the ethical judgement made by the public sector officers. The questionnaire is adapted from previous studies done by Victor and Cullen (1988), Suar and Khuntia (2004) and Amalina et al. (2014). The questionnaire was based on ten (10) item measures on management perception on ethical climate in the public sector. It used the seven-item Likert scales which range from $1=$ strongly disagree to $7=$ strongly agree.

\section{Conducting research and results}

The main purpose of the study is to examine the effects of ethical orientation, individual culture and ethical climate on public sector officers' ethical judgement. This section discusses results of data analysis.

\subsection{Data collection}

The researcher contacts the person in-charge of the selected government department by phone to get permission for the involvement of their staff. In November 2016, the questionnaires were sent directly by hand to the contact person together with the cover letter stating objectives of the study and the promise of anonymity and confidentiality of information. After three weeks, the questionnaires were self-collected from the contact person at his or her office. Out of 200 questionnaires distributed only 176 usable questionnaires were finalized which represented 88 percent response rate. This high percentage of response rate is justified with the convenience sampling method used in this study.

\subsection{Demography of participants}

The majority of the respondents of this study were female comprising 60.8 percent and male respondents representing 39.2 percent of the sample. From this analysis, a conclusion can be made that the public sector agencies are dominated by female. In this study, the majority of the respondents were Malay with 86.9 percent, 4.5 percent were Chinese, 5.1 percent were India and 3.4 percent comprised other ethnics groups. Most of the respondents were the ages of 30 to 40 years with 54.0 percent and the lowest percentage comes from the age of 50 and above with only 6.3 percent.

All of the respondents have accounting backgrounds and their minimum academic qualification is a bachelor's degree. In terms of job position, the majority of the respondents were in management and professional position with 98.3 percent whereby they were responsible for making decisions for their departments and agencies. The respondents were working in several departments related to accounting areas which are 19.3 percent of the respondent were in accounting department, 31.8 percent were in audit department, 15.9 percent were in finance department and 33.0 percent were in other departments.

From the analysis, respondents from other departments comprised of officers from the taxation department and some were in the department related to tax investigation and the forensic accounting department. In terms of grade, the majority of the respondents were in grade 
41 with 65.3 percent, 14.8 percent were in grade 44, 6.8 percent were in grade 48, 6.3 percent were in grade 52 and 54 and only 0.6 percent were in JUSA C grade.

The data also reveal that 59.1 percent of the respondents have five years and above of working experience in public sector agencies, which indicate that, they have been working with the public sector for a long period of time and possess a lot of experience. This also shows that they are able to make better decisions for their departments and agencies.

\subsection{Descriptive statistics}

The mean and standard deviation for all variables namely ethical orientation, individual culture and ethical climate is shown in Table 1. For the first variable which is ethical orientation, the overall means for idealism is 5.49 and the standard deviation is 1.60 , while the overall means for relativism is 3.36 and the standard deviation is 1.87 which is lower than that of idealism. For second variable, the overall mean for individual culture is 5.16 and the standard deviation is 1.32. Lastly, the overall means for ethical climate is 4.99 and the standard deviation is 1.46 .

Table 1. Means for independent variables

\begin{tabular}{lll}
\hline & Mean & Standard Deviation \\
\hline Ethical Orientation & & \\
$\quad$ Idealism & 5.49 & 1.60 \\
$\quad$ Relativism & 3.36 & 1.87 \\
\hline Individual Culture & 5.16 & 1.32 \\
\hline Ethical Climate & 4.99 & 1.46 \\
\hline
\end{tabular}

\subsection{Goodness of data}

Two analysis have been conducted in determining the goodness of data used in this study namely, factor analysis and reliability test.

\section{(i) Factor Analysis}

An exploratory factor analysis, using varimax rotations was performed to understand the structure of correlation of each variable. The Kaiser- Mayer Olkin coefficient for these dataset is 0.764 for idealism ethical orientation, 0.760 for relativism ethical orientation, 0.808 for individual culture and 0.763 for ethical climate. In addition, the Bartlett test of Sphericity for idealism ethical orientation (Chi- Square $=563.858, \mathrm{p}<0.000$ ), relativism ethical orientation (Chi- Square $=548.497, \mathrm{p}<0.000)$, individual culture $($ Chi- Square $=772.907, \mathrm{p}<$ $0.000)$ and ethical climate (Chi- Square $=559.581, \mathrm{p}<0.000)$.

(ii) Reliability Test

The Cronbach's alpha reliability coefficients for idealism and relativism are 0.770 and 0.835 , and a standardized item alpha are 0.801 and 0.834 respectively. The Cronbach's alpha reliability coefficient for individual culture is 0.775 and standardized item alpha 0.808 . Meanwhile, Cronbach's alpha for ethical climate is 0.757 and 0.770 for standardized item alpha.

\subsection{Test of data}

The study performs a multicollinearity test using the correlation analysis and collinearity statistics. A multicollinearity problem occurs when the correlations between independent variables are more than 0.7 (Pallant, 2007). See Table 2 for results of correlation matrix. Results 
show that values of correlation coefficient between independent variables are in the range of 0.19 and .44 . Since the correlations are less than 0.7 there is no serious multicollinearity problem, hence, all variables are retained for further analysis (Pallant, 2007).

Table 2. Test of Correlation between variables

\begin{tabular}{lccccc}
\hline & EJ & IEO & REO & IC & EC \\
\hline $\begin{array}{l}\text { Ethical Judgment } \\
\text { (EJ) }\end{array}$ & 1 & & & & \\
\hline Idealism & & & & & \\
Ethical Orientation (IEO) & $-.275^{* *}$ & 1 & & & \\
\hline $\begin{array}{l}\text { Relativism } \\
\text { Ethical Orientation (REO) }\end{array}$ & .236 & -.188 & 1 & & \\
\hline Individual Culture (IC) & $-.222^{* *}$ & $.185^{* *}$ & $-.278^{* *}$ & 1 & \\
\hline Ethical Climate (EC) & -.194 & $.263^{* *}$ & -.294 & $.437^{* *}$ & 1 \\
\hline
\end{tabular}

**. Correlation is significant at the 0.01 level (2-tailed).

*. Correlation is significant at the 0.05 level (2-tailed).

\subsection{Results of multiple regression analysis}

This study uses multiple regressions analysis to assess the effects of ethical orientation, individual culture and ethical climate on public sector officers' ethical judgement. The regression model as shown in Table 3 is significant with $F=5.563$. The adjusted $R$ Square is 0.294 , which indicates that the model has successfully explained $29.4 \%$ of the variance in public sector officers' ethical judgement. This level of adjusted R square is comparable to that in some other studies (Naibei et al., 2014). The analysis is based on a sample of 248 cases, which is considered adequate (Tabachnick \& Fidell, 2007). Table 5 presents results of the multiple regression analysis.

Table 3. Regression analysis

\begin{tabular}{|c|c|c|c|c|}
\hline Variables & $\begin{array}{l}\text { Standardized } \\
\text { Coefficient }\end{array}$ & $\begin{array}{l}\text { Std. } \\
\text { Error }\end{array}$ & t-stat & p-value \\
\hline Constant & & 1.513 & 7.159 & .000 \\
\hline $\begin{array}{l}\text { Idealism } \\
\text { Orientation }\end{array}$ & -.254 & .025 & -3.398 & $.001^{\mathrm{a}}$ \\
\hline $\begin{array}{l}\text { Relativism } \\
\text { Orientation }\end{array}$ & .091 & .018 & 1.215 & .226 \\
\hline Individual Culture & -.169 & .026 & -2.030 & $.044^{\mathrm{a}}$ \\
\hline Ethical Climate & .045 & .022 & .549 & .584 \\
\hline $\begin{array}{l}\mathrm{R}=.339^{\mathrm{a}} \\
\mathrm{R}^{2}\left(\text { Adjusted } \mathrm{R}^{2}\right)= \\
\mathrm{F} \text {-statistic }(\mathrm{p} \text {-value) } \\
\text { Durbin Watson stat } \\
\text { Significance at } \mathrm{p}<\end{array}$ & $\begin{array}{l}294 \\
=5.563(0.000 \\
\text { stic }=1.473 \\
.05\end{array}$ & & & \\
\hline
\end{tabular}

Table 3 above indicates the overall analysis for this study. From the analysis, the adjusted $\mathrm{R}^{2}$ value is 0.294 which means that 29.4 percent of the variation in the ethical judgement could be explained by ethical orientation, individual culture, and ethical climate. 
Based on Table 3, idealism shows a significant negative relationship with ethical judgement when the coefficient value for idealism is $-0.254, \mathrm{t}=-3.398, \mathrm{p}=0.001$. Therefore, H1 (a) is supported. However, the result for relativism shows no influence between relativism and ethical judgement as the coefficient value is $0.091, \mathrm{t}=1.215, \mathrm{p}=0.226$. Therefore, $\mathrm{H} 1$ (b) is not supported. The individual culture variable shows the significant negative relationship with ethical judgement with the coefficient value of $-0.169, t=-2.030$ and $p=0.044$. As a result, $\mathrm{H} 2$ is supported. Finally, the last variable (ethical climate) shows no influence on ethical judgement as the coefficient value is $0.045, \mathrm{t}=0.549, \mathrm{p}=0.584$ respectively. Therefore, $\mathrm{H} 3$ is not supported.

\section{Discussion of the findings}

In this study, the number of respondents was 39.2 percent males and 60.8 percent females. More than half of the respondents were in the age group of 30 to 40 years old (54.0 percent), 26.7 percent made up the age group of 30 years and below, 13.1 percent for the age group of 41 to 50 years old and 6.3 percent for the age group of 51 years old and above. The majority of the respondents were Malay with 86.9 percent whereas the other races were 4.5 percent, 5.1 percent and 3.4 percent for Chinese, India and others respectively. From this study, the majority of the respondent are working in the service grade of 41 and above, where they are responsible for making decisions in their organization. Therefore, their ethical judgement is very important for the integrity and credibility of their organization. The questionnaires were used in this study in order to examine the relationships between ethical orientation, individual culture as well as ethical climate on the ethical judgement of the public sector officers.

Hypotheses H1 (a) and H1 (b) predict the influences of idealism and relativism ethical orientation on the public sector officers' ethical judgements. From the analysis obtained, it is found that idealism ethical orientation had a significant negative relationship with ethical judgement, in which it supports the hypothesis $\mathrm{H} 1$ (a). This finding is consistent with some previous research that showed idealism is significantly and negatively related with ethical judgement (e.g. Barnett et al., 1994; 1998; Douglas \& Wier, 2005). As noted in Ismail (2014), this finding provides further evidence that the public sector officers are the extreme idealistic persons who assume that wrong actions are acceptable with 'reasonable' reasons and believe the consequences will not harm others (Forsyth, 1980).

This finding is inconsistent with other previous studies that found the positive effect of idealism ethical orientation on ethical judgement (e.g. Abou Hashish \& Ali Awad, 2017; Johari et al., 2017; Ozbek, Alniacik, Akkilic \& Koc, 2013). The differences of this finding might be due to the respondents' profession, gender, age, education level, etc. In general, the respondents might be willing to sacrifice ethical standards for individual or firm financial reward as they react negatively to the ethical judgement. The public sector officers' may consider ethical dilemmas faced by them is not a serious mistake, hence they perform unethical judgement to fulfil their personal benefits since they are the extreme idealistic person. They believe that their action does not affect their organization and society.

On the other hand, the result of this study also found that there was no significant relationship between relativism ethical orientation and ethical judgement. This finding is consistent with previous studies such as Barnett et al., (1994); Hartikainen and Torstila (2004). In addition, Ballantine and McCourt (2010) also found the same finding that supported the insignificant relationship between relativism ethical orientation and ethical judgement. With this justification, H1 (b) is rejected.

The second hypothesis $\mathrm{H} 2$ predicts a relationship between individual culture and ethical judgement of the public sector officers. From the analysis, it is found that the individual culture has a significant negative influence on the public sector officers' ethical judgement. This 
finding is consistent with the finding of previous studies such as Ringov and Zollo (2007) as well as Singhapakdi and Vitell (1990). Therefore, hypothesis H2 in this study is supported. The finding indicates that the public sector officers possess the low level collectivism culture which also contradicts the result of other studies such as Wang et al., (2017); Hunt and Vitell (1986); Jeffrey et al. (2004). The inconsistency of this result might be due to the fact that the respondents of this study are the officers from Management and Professional group who can make their own judgement based on their education level, grade of services and ages.

The result reveals that this group of respondents are more independent in making decision and they prefer to make decision personally without having any discussion with their colleagues. This finding is consistent with Oyserman, Coon and Kemmelmeier (2002) who noted that people with low level collectivism culture are unique and independent in making any judgement. This fact justifies the finding of this study where the low level collectivist person tend to place greater importance on achieving tasks than in maintaining harmonious relationship (Oyserman et al., 2002).

The last hypothesis $\mathrm{H} 3$ predicts that there is a relationship between ethical climate and ethical judgement made by public sector officers. However, the analysis shows that there is no significant relationship between ethical climate and ethical judgement. This result is inconsistent with Abou Hashish (2017), Amalina et al., (2014) and Valentine and Barnett (2007) where they found a significant relationship between ethical climate and ethical judgement. Therefore, the hypothesis H3 is rejected. The finding indicates that ethical climate has no influence on the public sector officers' ethical judgement.

This result could be due to the sample selected in this study which is based on the public sector officers' education level and service grade. Pan and Sparks (2012) mentioned that education may open the minds of an individual and enhances his reasoning as well as judgement. This means that once an individual has a high education level, the individual will be able to make ethical judgements regardless the organization's climate. When an individual is given responsibility for making decisions for their organization, the individual who is highly educated tends to make an ethical decision for the best interest of their organization as a whole. Therefore, in this study ethical climate has no relationship with ethical judgement due to the respondents' education level and working grade.

\section{Conclusion}

This study is carried out to examine the behaviours of public sector officers in making the best decision for their organization. In this study three variables are used to investigate the factors that are believed to influence ethical judgements. Hence, this study offers some recommendations for public sector agencies, professional bodies as well as educational institutions. In the public sector, ethical judgement of the officers can be improved by implementing rules, guidelines and penalties to each individual who is involved in unethical conducts; hence this study can be used to shape the behaviour of public sector officers in Malaysia.

In addition, this study also contributes to the public sector officers and academics in both practical and theoretical aspects as it provides information about ethical judgement issues among public sector officers in Malaysia. This issue is important to be highlighted as it is critical for the development of the nation as a whole. Apart from that, this study also provides information on factors that influence the ethical judgements made by public sector officers which are ethical orientation, individual culture and ethical climate. Furthermore, it contributes to theoretical aspects, where it will provide the latest literature related to issues on ethical judgements. 
Theoretically, this study combines three factors from Bandura Social Cognitive Theory (1986) which includes the elements of environment, person and behaviour. Ethical orientation and individual culture are recognized to be the personal factors that influence individuals' behaviour whereas ethical climate is recognized as environment factor and finally, the behaviour factor is represented by the public sectors officers' ethical judgement. It is believed that these elements can influence individuals in making their ethical judgement. In previous studies, Bandura Social Cognitive Theory (1986) was rarely used to analyze the factors that influence individuals' ethical judgement. Hence, this research provides information on the factors that influence individuals in making ethical decision.

In another point of view, it is revealed from this study that public sector officers are categorised as extreme idealistic persons when the result of the finding for idealism ethical orientation is negative. Ismail (2014) mentioned that extreme idealistic individuals tend to assume that wrong actions are acceptable and their action will not harm others. In addition, public sector officers also belong to those who have low level of collectivism culture when the finding for individual culture is also negative. Hence, it could be assumed that this study provides information on how public sector officers perform their judgement and encourage government agencies to adapt more positive idealism ethical orientation and collectivism culture.

Apart from that, understanding and awareness on the importance of making ethical judgement among public sector officers are gained especially for those who are responsible in managing the wealth of the nation. This is because the aim of conducting this study is to create and improve the awareness of public sector officers in ensuring that they are able to perform their duties with integrity and credibility. This study also provides recommendations to public sector agencies, such as the need to impose stricter penalties and increase enforcement to monitor unethical conducts among public sector officers as well as create an ethical working environment for the officers.

\section{Limitations and recommendations}

This study has several limitations and these limitations creates recommendations for future studies. Firstly, the data collected for this research were from only four public sector agencies which are Accountant General's Department of Malaysia (Jabatan Akauntan Negara), National Audit Department (Jabatan Audit Negara), Royal Malaysian Customs Department GST Department (Jabatan Kastam Malaysia- Jabatan GST) and Inland Revenue Board of Malaysia (Lembaga Hasil Dalam Negeri). Whereas, there are many other public sector agencies in the federal, state, federal statutory bodies, state statutory bodies as well as local enforcement authorities. Therefore, the data collected might not be sufficient to obtain an accurate result for this study. Hence, future studies should attempt to replicate and use larger and more varied samples of the target respondents and include other public sector officers in other different departments and agencies. Next, the variables used for this study were selected in random based on the previous literatures with findings on the relationships between ethical judgement and these variables. However, in the real environment, there are many other factors which influence the judgement made by an individual. As a result, other variables such as emotional intelligence, work pressures and ethical sensitivity can be used to examine relationships on public sector officers' ethical judgement in future studies. 


\section{References}

Abou Hashish, E. A., \& Ali Awad, N. H. (2017). Relationship between ethical ideology and moral judgment: Academic nurse educators' perception. Nursing Ethics, online: September 11, 2017 https://doi.org/10.1177/0969733017722825

Abou Hashish, E. A. (2017). Relationship between ethical work climate and nurses' perception of organizational support, commitment, job satisfaction and turnover intent. Nursing Ethics, 24(2), 151-166.

Alam, M. M., Johari, R. J. \& Said. J. (2018). An empirical assessment of employee integrity in the public sector of Malaysia. International Journal of Ethics and Systems, https://doi.org/10.1108/IJOES01-2018-0006

Amalina, A., Zunaidah, S., \& Ridzwana, M.S. (2014). An analysis on ethical climate and ethical judgement on public sector employees in Malaysia. Journal of Applied Business and Economics, 16(2), 133-142.

Arnold, D.F., Bernadia, R.A., Neidermeyer, P.E., \& Schmee, J. (2007). The effect of country and culture on perceptions of appropriate ethical actions prescribed by codes of conduct: A Western European perspective among accountants. Journal of Business Ethics, 70(4), 327-340.

Axinn, C., Blair, M., \& Thach, A. (2004). Comparing ethical ideologies across cultures. Journal of Business Ethics, 54(2), 103-119.

Ballantine, J. \& McCourt P. (2010). The impact of ethical orientation and gender on final year undergraduate auditing students' ethical judgements. Accounting Education: An International Journal, 20(2), 187-201.

Bandura, A. (1986). Social foundations of thought and action: A social cognitive theory. Englewood Cliffs, NJ: Prentice- Hall, Inc.

Barnett, T., Bass, K., \& Brown, G. (1994). Ethical ideology and ethical judgement regarding ethical issues in business. Journal of Business Ethics, 13(6), 469-480.

Bass, K., Barnett, T., \& Brown, G. (1998). The moral philosophy of sales managers and its influence on ethical decision-making. Journal of Personal Selling \& Sales Management, 18(2), 1-17.

Berrone, P., Surroca, J. \& Tribo, J.A. (2007). Corporate ethical identity as a determinant of firm performance: A test of the mediating role of stakeholder satisfaction. Journal of Business Ethics, 76(1), 35-53.

Burton, F. G. (2017). Discussion of national culture and ethical judgment: a social contract approach to the contrast of ethical decision making by accounting professionals and students from the US and Italy. Journal of International Accounting Research, 16(2), 121-126.

Colby, A. \& L. Kohlberg (1987). The measurement of moral judgement. Cambridge University Press, Cambridge.

Dieterly, D., \& B. Schneider (1974). The effect of organizational environment on perceived power and climate: A laboratory study. Organizational Behaviour and Human Performance, 11, 316-337.

Douglas, P.C., \& Wier, B. (2000). Integrating ethical dimensions into a model of budgetary black creation. Journal of Business Ethics, 28(December), 267-278.

Douglas, P., R. Davidson, \& B. Schwartz (2001). The effects of organizational culture and ethical orientation on accountants' ethical judgements. Journal of Business Ethics, 34(2), 101-121.

Forsyth, D.R. (1980). A taxonomy of ethical ideologies. Journal of Personality and Social, 39(1), 175-184. 
Gonzalez-Padron, T., Hult, G.T.M., \& Calantone, R. (2008). Exploiting innovative opportunities in global purchasing: An assessment of ethical climate and relationship performance. Industrial Marketing Management, 37(1), 69-82.

Hartikainen, O. \& S. Torstila (2004). Job related ethical judgement in the finance profession. Journal of Applied Finance (JAF), 14(1), 62-76.

Hofstede, G. (1980). Culture's consequences: International differences in work related values. Sage, Newbury Park, CA.

Hofstede, G.H. (1983). The cultural relativity of organizational practices and theories. Journal of International Business Studies, 14, 75-89.

House, R.J., Hanges, P.J., Javidan, M., Dorfman, P.W., \& Gupta V. (2004). Culture, leadership, and organizations. The GLOBE Study of 62 Societies, Sage Publications, Inc.

Hunt, S.D. \& Vitell, S.J. (1986). A general theory of marketing ethics. Journal of Macromarketing, 6, 5-16.

Hunt, S.D., Wood, V.R., \& Chonko, L.B. (1989). Corporate ethical values and organizational commitment in marketing. Journal of Marketing, 53(3), 79-90.

Ismail, S. (2014). Effect of ethical ideologies on ethical judgement of future accountants: Malaysian evidence. Asian Review of Accounting, 22(2), 145 -158.

Jeffrey, C., Weatherholt, N., \& Lo, S. (2004). Ethical development professional commitment and rule observance attitudes: A study of auditors in Taiwan. The International Journal of Accounting, 31(3), 365-379.

Johari, R. J., Alam, M. M., \& Said, J. (2018). Assessment of Management Commitment in Malaysian Public Sector. Cogent Business \& Management, 5: 1469955 https://doi.org/10.1080/23311975.2018.1469955

Johari, R. J., Mohd. Sanusi, Z. \& Vincent, K. C. (2017). Effects of auditors' ethical orientation and self-interest independence threat on the mediating role of moral intensity and ethical decision-making process. International Journal of Auditing. 21 (1), 38-58.

Johari, R.J., Sanusi, M.Z., \& Ismail, A.H. (2012). Exploratory factor analysis of the ethical orientation scale. Asian Journal of Accounting and Governance, 3, 1-11.

Jones, T.M. (1991). Ethical decision making by individuals in organizations: An issuecontingent model. Academy of Management Review, 16, 366-395.

Jung, J.M. (2002). Interactive impact of culture and individual characteristics on ethical decision-making processes, criteria, and judgemental outcomes: A cross-national comparison between South Korea and United States. A dissertation submitted to the Division of Research and Advanced Studies of the University of Cincinnati.

Maheran, Z. (2010). An analysis on ethical judgements of Malaysian auditors. Unpublished thesis, Universiti Teknologi Mara, Shah Alam, Malaysia.

Martin, K.D. \& Cullen, J.B. (2006). Continuities and extensions of ethical climate theory: A meta-analytic review. Journal of Business Ethics, 69(2), 175-194.

McKee, G.H. (1988). Multi-level investigation of absence climate: Individuals, supervisory groups, and plants, Unpublished dissertation, Virginia Polytechnic Institute and State University, Blasckburg, Virginia.

Oyserman, D., Coon, H.M. \& Kemmelmeier, M. (2002). Rethinking individualism and collectivism: Evaluation of theoretical assumptions and meta-analyses. Psychological Bulletin, 128(1), 3-72.

Ozbek, V., Alniacik, U., Akkilic, M.E. \& Koc, F. (2013). The moderating role of locus of control on the link between perceived ethical problem and ethical intentions of marketing managers in Turkey. Procedia - Social and Behavioural Sciences, 99, 265-273.

Pan, Y., \& Sparks, J.R., (2012). Predictors, consequence, and measurement of ethical judgements: Review and meta-analysis. Journal of Business Research, 65, 84-91. 
Ringov, D. \& Zollo, M. (2007). The impact of national culture in corporate social performance. Corporate Governance, 7(4), 476-485.

Shafer, W.E. (2008). Ethical climate in Chinese CPA firms. Accounting, Organizations and Society, 33, 825-835.

Shafer, W.E. \& Wang, Z. (2011). Effects of ethical context and Machiavellianism on attitudes toward earnings management in China. Managerial Auditing Journal, 26,372-392.

Singhapakdi, A. \& Vitell, S.J. (1990). Marketing ethics: Factors influencing perceptions of ethical problems and alternatives. Journal of Macromarketing, (Spring): 4-18.

Singhapakdi, A., S. J. Vitell, \& G.R. Franke (1999). Antecedents, consequences, and mediating effects of perceived moral intensity and personal moral philosophies. Journal of the Academy of Marketing Science, 27(1), 19-36.

Stanga K. \& Turpen, R. (1991). Ethical judgements on selected accounting issues: An empirical study. Journal of Business Ethics, 10(10), 739-747.

Suar, D. \& Khuntia, R. (2004). Does ethical climate influence unethical practices and work behaviour? Journal of Human Values, 10(1), 11-21.

Sullivan A.C. (2007). The effects of ethical orientation and academic discipline on accounting students' use of professional judgement. Applied Management and Decision Sciences.

Valentine, S.R. \& Barnett, T. (2007). Perceived organizational ethics and the ethical decisions of sales and marketing personnel. Journal of Personal Selling \&Management, 27(4), 373388.

Victor, B. \& Cullen, J.B. (1987). A theory and measure of ethical climate in organization. In W.C Fredic and L.E. Preston, eds. Research in Social Performance and Policy, 9, 51-71, Greenwich, T: JAI Press.

Victor, B., \& Cullen, J.B. (1988). The organizational basis of ethical work climates. Administrative Science Quarterly, 33(91), 101-125.

Wang, H., Lu, G. \& Liu, Y. (2017). Ethical Leadership and Loyalty to Supervisor in China: The Roles of Interactional Justice and Collectivistic Orientation. Journal of Business Ethics, 146(3), 529-543. 